\title{
Effects of winter fishery activities on resting numbers, food and body condition of large gulls Larus argentatus and $L$. marinus in the south-eastern North Sea
}

\author{
O. Hüppop*, S. Wurm \\ Institut für Vogelforschung 'Vogelwarte Helgoland', Inselstation, PO Box 1220, 27494 Helgoland, Germany
}

\begin{abstract}
C Influences of fishery activities on herring gulls and great black-backed gulls (Larus argentatus, L. marinus) wintering on the island of Helgoland, south-eastern North Sea, were studied. When cod fishery discards were available close to the island. 83 to $87 \%$ of the gulls' pellets contained fishery discard remains and 70 to $73 \%$ of all pellets consisted exclusively of these. At times when no nearby trawling took place (Christmas/New Year), numbers of herring gulls dropped by up to $86 \%$ and numbers of great black-backed gulls by up to $80 \%$. Similar declines were observed during a trawling moratorium in February 1998. Adults of both gull species had a significantly lower body mass during periods of no fishing around the island (13 and $24 \%$ less, respectively). Retraps of single gulls support these findings. The results show for the first time a strong influence of discard availability on numbers and body condition of large gulls wintering in the south-eastern North Sea. Effects on gull winter mortality and thus on population dynamics can be assumed.
\end{abstract}

KEY WORDS: Fisheries · Herring gull - Great black-backed gull - Resting numbers · Food - Fishery discards - Body condition - North Sea

\section{INTRODUCTION}

Several authors have attributed the population increase and range expansion of many scavenging seabird species, at least partly, to their utilisation of fishery discards (unused bycatch) and offal (e.g. Nisbet 1978, Furness 1982, Montevecchi 1993, Oro et al. 1995, Oro 1996, Chapdelaine \& Rail 1997, Hagemeijer \& Blair 1997).

Some studies show that the availability of fishery discards and offal may affect seabird population dynamics. For example, in the absence of fishery discards in the north-western Mediterranean, the reproductive output of Audouin's gulls Larus audouinii dropped markedly (Paterson et al. 1992), and reduced

•E-mail: o.hueppop-ifv@t-online.de egg volume and breeding success were detected in lesser black-backed gulls $L$. fuscus (Oro 1996). Oro et al (1995) showed that a trawling moratorium which overlapped with the chick-rearing stage affected the breeding success of the yellow-legged gull $L$. cachinnans in the Ebro Delta. The diurnal pattern of Audouin's gulls present on a small island in the northwestern Mediterranean Sea in the pre-breeding period differed significantly between fishing and non-fishing days (Castilla \& Pérez 1995), and a decline in numbers of breeding herring gulls $L$. argentatus at the Gulf of St. Lawrence (Canada) appeared to be related to a decrease in commercial fishing activities in that region (Chapdelaine \& Rail 1997).

There is also strong evidence that scavenging seabirds in the North Sea benefit from fishing since they join fishery vessels in large numbers (Hudson \& 
Furness 1988, Garthe \& Hüppop 1994, Camphuysen et al. 1995, Walter \& Becker 1997), while discards and offal are quantitatively important components of many seabirds' diet (Hunt \& Furness 1996). The amount of fishery waste available in the North Sea is, at least theoretically, sufficient to satisfy the energy demands of all scavenging species (Garthe et al. 1996). However, the question of whether the availability of fishery discards and offal actually affects North Sea seabird populations remains open.

Since there is virtually no area without fishery activities throughout the whole North Sea, seabird population dynamics under the influence of fisheries cannot be compared to those under natural conditions. However, some comparisons are possible an a temporal scale. In the German Bight close to the island of Helgoland $\left(54^{\circ} 11^{\prime} \mathrm{N}, 7^{\circ} 55^{\prime} \mathrm{E}\right.$ ) there is an intensive winter fishery with otter trawls for cod Gadus morhua. This fishery is generally suspended from about Christmas to New Year ('Christmas gap'), which markedly reduces the numbers of herring gull and great black-backed gull Larus marinus resting on the island of Helgoland (Hüppop \& Geiß 1995). Furthermore, a fishery moratorium (the very first in the German Bight) lasted throughout February 1998. It aimed to reduce mortality in cod of the very large year class 1996 (Weber \& Ehrich 1998). Both the Christmas gap and the fishing moratorium offered the opportunity to test to what extent the availability of fishery discards and offal influences (1) the food choice of large gulls resting on Helgoland; (2) their resting numbers; and (3) their body mass as an indicator of condition of the gulls.

\section{METHODS}

Trawler activity. We counted all fishing trawlers in range of sight of Helgoland from 3 December 1997 to 30 March 1998. Therefore we inspected the horizon with a $20 \times$ telescope from the top of the Helgoland lighthouse ( $80 \mathrm{~m}$ above sea level) or from other prominent elevated sites (roughly $50 \mathrm{~m}$ high) once a day between 11:00 and 14:00 h. On several foggy days with poor visibility the possibility of overlooking some trawlers was very high, so we distinguished between days with and without visibility of at least $5 \mathrm{~km}$. Distance estimates were validated by radar checks from the lighthouse

Diet. In total, 233 'fresh' pellets (i.e. pellets still covered with mucous) were collected on piers, where the gulls usually rest during the night: 106 pellets were collected in periods with fisheries (5 December 1997 , $\mathrm{n}=52$ peliets, and 13 January $1998, \mathrm{n}=54$ ) and 127 in periods without fisheries (21 and 28 December 1997. $\mathrm{n}=70$, and 25 February 1998, $\mathrm{n}=57$ ). Since herring gulls and great black-backed gulls usually rest together on Helgoland, it is impossible to distinguish between their pellets. After drying at $60^{\circ} \mathrm{C}$, we examined each pellet under a binocular microscope. In nearly all cases it was possible to identify their different components. Fish remains could mostly be identified to species with the help of otoliths and jaws using a reference collection and the guides of Härkönen (1986) and Watt et al. (1997). For this analysis it was sufficient to group the pellets into 5 categories: discard fish, discard invertebrates, non-discard fish, non-discard marine invertebrates (including hooknose eggs) and terrestrial food (including garbage). All pellets containing the remains of subtidal animals that gulls usually reach only by capturing them behind trawlers (e.g. cod, whiting Merlangius merlangus, scad Trachurus trachurus, the polychaete Aphrodite aculeata, and large starfish Asterias rubens) were assigned to the respective discard categories. In a very few cases the origin of the consumed animals remained doubtful (e.g. spider crab Hyas araneus and swimming crab Liocarcinus $\mathrm{sp}$.). If there were no unequivocal remains of other discard organisms, these pellets were classified as 'non-discard'.

Body condition. Body mass in relation to head + bill length (measured with callipers from the back of the head to the tip of the bill with an precision of $0.1 \mathrm{~mm}$ ) was used as an indicator of body condition (Coulson et al. 1983). As many gulls as possible were caught at their night roosts on piers between 7 December 1997 and 26 February 1998 by dazzling them with a strong halogen torch and covering them with a hand net (Stühmer \& Röw 1988). Since gulls that have recently fed usually regurgitate when handled, a possible bias in body mass due to different stomach contents can be excluded. Although this method resulted in only a few catches per night ( 0 to 5$)$ and gulls learned to avoid trapping, we decided not to trap the birds by using bait. This could have led to a bias towards birds in poorer condition. Capturing by canonnetting was not feasible. Each gull was weighed to the nearest $1 \mathrm{~g}$ (birds less than $2 \mathrm{~kg}$ ) or to the nearest $5 \mathrm{~g}$ (birds more than $2 \mathrm{~kg}$ ), and aged by plumage characteristics. Birds $<3$ yr old were categorised as 'immature', and those 3 yr and older as 'adult'. Because of the small sample size we pooled data with respect to fishing activity.

Gull counts. Since 1989 all 'waterbirds', including gulls resting on Helgoland, have been counted once every spring tide at high tide around noon. This schedule is similar to that established by Rösner \& Prokosch (1992) in the Wadden Sea of Schleswig-Holstein. Two additional counts were carried out in December 1997 and January 1998 to explore the effects of the Christmas gap. 


\section{RESULTS AND DISCUSSION}

\section{Trawler activity}

In the first half of December 1997 trawler activity was very high (mainly otter trawlers and a few beam trawlers). On days of good visibility, up to 11 fishing trawlers were observed. From 16 December, trawler activities ceased around Helgoland because of stormy weather (which lasted until the usual Christmas gap). Fishing resumed on 8 January 1998. Only 1 trawler

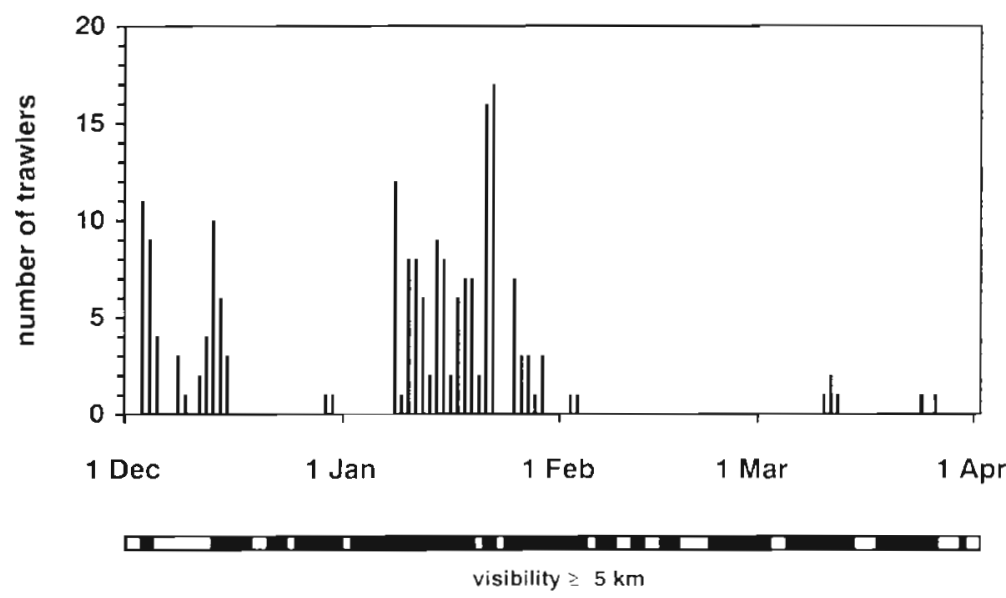

Fig. 1. Trawler activity around Helgoland during winter 1997/98. The black parts of the horizontal bar indicate days with visibility of $\geq 5 \mathrm{~km}$

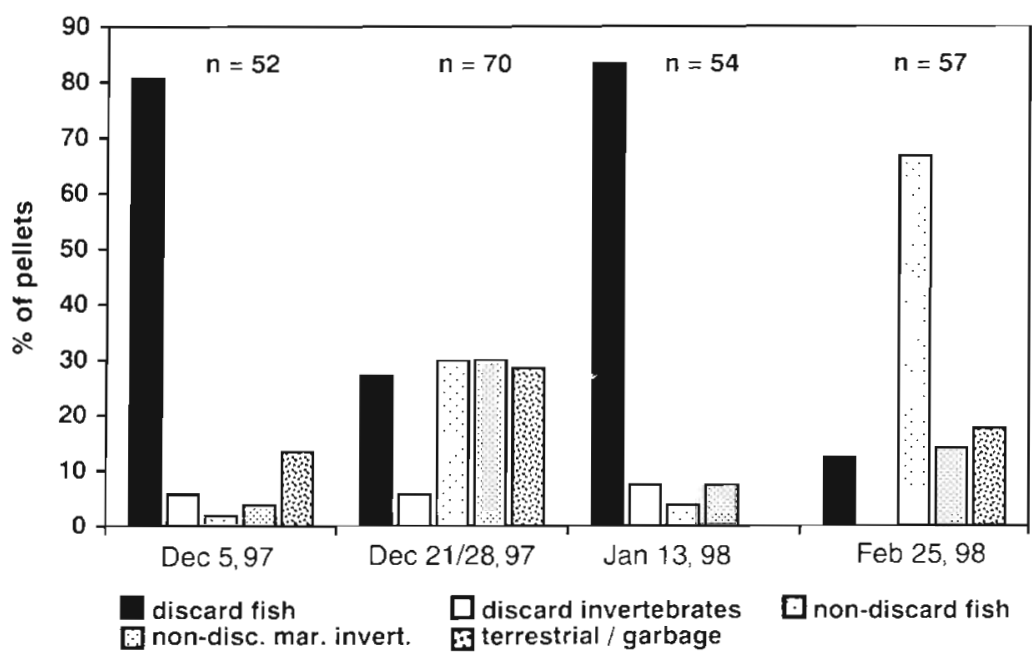

Fig. 2. Pellet contents in the 4 collections carried out during winter 1997/98. Food remains were grouped into discard fish, discard invertebrates, non-discard fish, non-discard marine invertebrates (including hooknose eggs) and terrestrial food (including garbage). Food remains with doubtful origin are not taken into account. Since different food categories may appear in a single pellet, the totals of the percentages exceed 100 was observed just before the turn of the year but stayed only $2 \mathrm{~d}$. In the following days of January, fishing was even more intensive than in December. The number of trawlers rose to 17 on 22 January. The portion of cod of year class 1996 in their catches was so high that the German government imposed a moratorium on all kinds of fishery in a $12 \times 25$ nautical mile rectangle around Helgoland for the whole of February 1998. It is estimated that 2 million undersized cod were discarded from November 1997 to January 1998 (Weber \& Ehrich 1998). Although the moratorium ended on 28 February 1998, there was virtually no further trawler activity until the end of our study, the cod having migrated to other areas (Weber \& Ehrich 1998). Even in the last days of January, before the moratorium, there were fewer trawlers, so maybe the cod had already at that time begun to emigrate.

In total, the stormy days before Christmas, the Christmas gap, the fishing moratorium and the emigration of cod resulted in 2 periods of very little trawler activity around Helgoland (16 December to 7 January, 4 February to 30 March). In contrast, there were 2 periods of intensive trawler activity in December and January (Fig. 1).

\section{Diet}

Striking differences in diet were detected between periods with and without fishery activities (Fig. 2). Each transition between successive periods with/without fisheries shows a highly significant difference in the percentage of pellets containing discards (Table 1). At times of intensive trawler activity, more than $80 \%$ of the pellets contained discards (fish and/or invertebrates). Indeed, 73 and $70 \%$ of all pellets, respectively, comprised remains that presumably originated exclusively from discards. This shows that the gulls mainly fed on discards when they were available. Cod was the most dominant discard species found, whereas whiting, scad, Aphrodite aculeata and other species occurred only in a few pellets.

At times of no fishery activity around Helgoland, the gulls concentrated on food items of the rocky intertidal zone (mainly hooknose Agonus cataphractus, hooknose eggs, shore crab Carcinus maenas, and mussels Mytilus edulis), terrestrial food (such as earthworms, dipterean larvae, other birds or mammals) and garbage. However, some pellets never- 
Table 1. Percentage of pellets with and without discard remains in the 4 pellet collections carned out during winter $1997 / 98$ Differences between the single collections were tested for significance by G-tests (always $p<0.001$ after Bonferroni-adjustment; Sachs 1997)

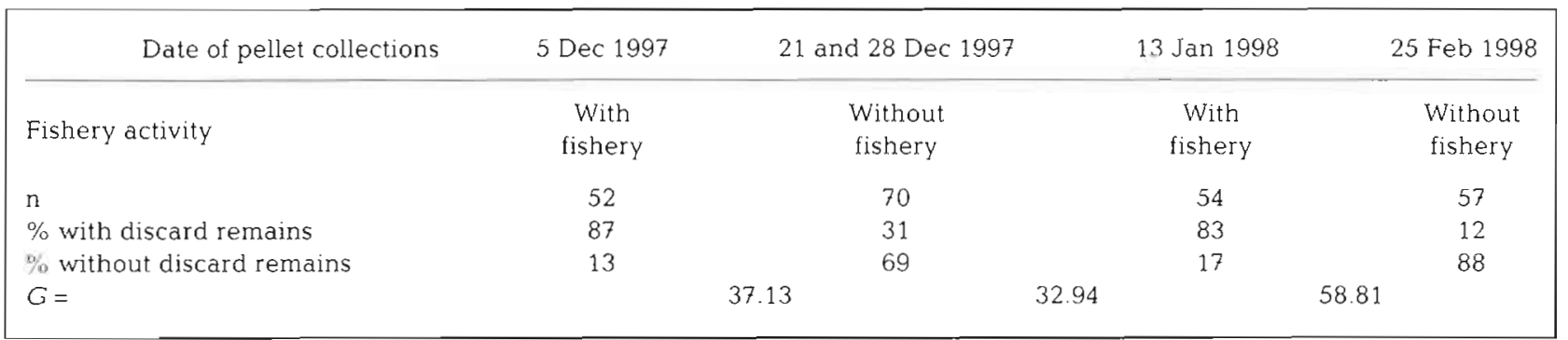

theless contained presumed discard remains. It cannot be excluded that some gulls took discards (1) from trawlers beyond our visibility, trawling e.g. during the stormy days before Christmas in areas with smaller
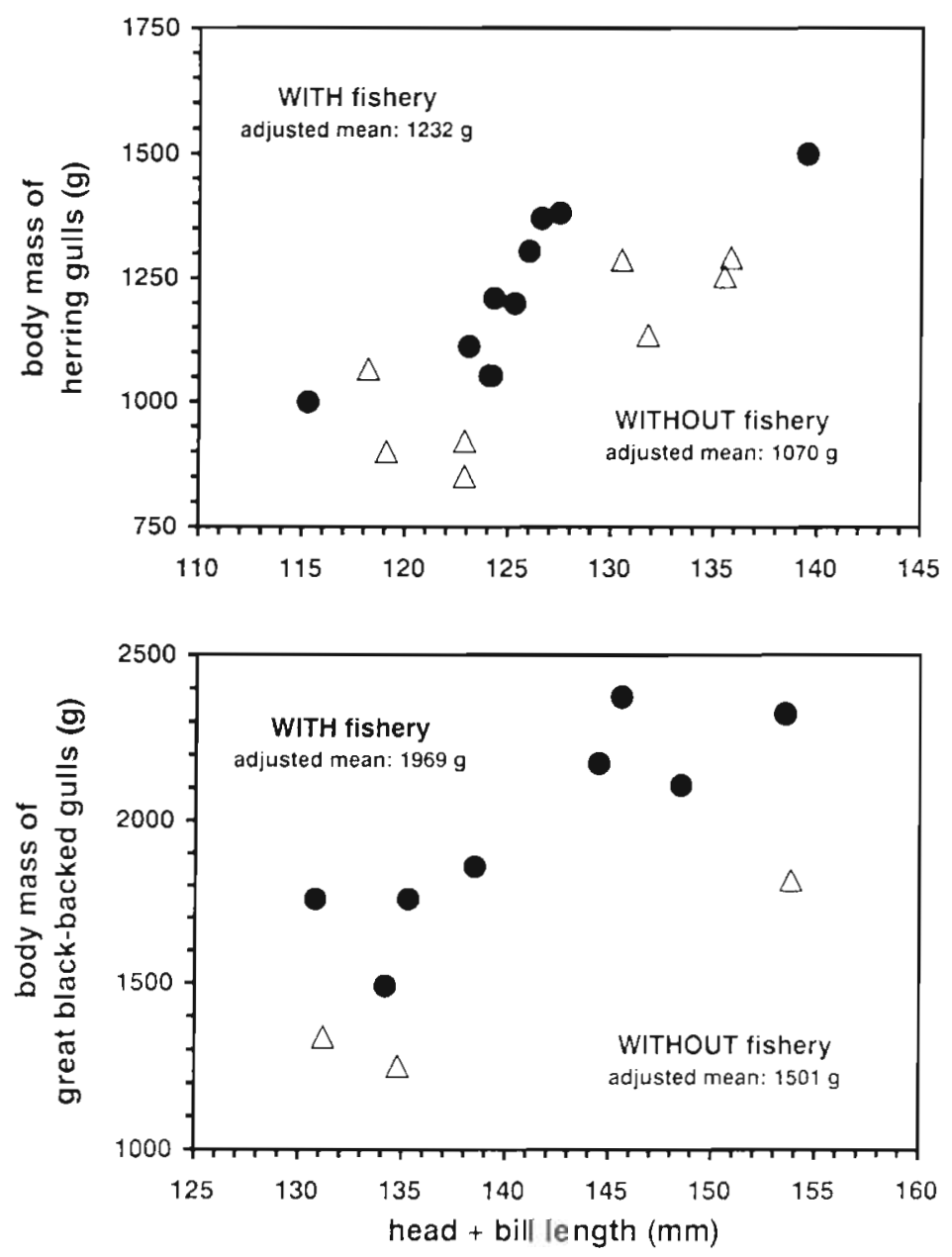

Fig. 3. Body mass in relation to head + bill length of adult herring gulls and adult great black-backed gulls at times with (-) and without $(\Delta)$ fishery activity during winter $1997 / 98$. Note the different scales waves closer to the coast; (2) during the Christmas gap contrary to the general holiday habits at that time; or (3) outside the moratorium rectangle. The foraging range of gulls may easily exceed the range that was covered by our trawler counts. Spaans (1971) gave a feeding range of $35 \mathrm{~km}$ for breeding herring gulls in a Dutch colony and Sell \& Vogt (1986) reported on foraging trips of up to $41 \mathrm{~km}$ in North Rhine-Westphalia outside the breeding season. Klein (1994) suggested foraging trips of 70 to $100 \mathrm{~km}$ for herring gulls breeding in Denmark.

\section{Body condition}

Fishing activity strongly affected body mass of the gulls (Fig. 3). Despite the small sample size, an ANCOVA revealed highly significant effects of head + bill length (as a measure of body size) and of fishing activity on body mass, both in adult herring gulls ( $F=32.00, \mathrm{p}<0.001$ and $F=$ 11.32, p < 0.005 , respectively) and in adult great black-backed gulls $(F=26.37, p<0.001$ and $F=$ $18.88, p<0.002$, respectively). After standardising body mass for the effects of head + bill length, mean body mass of adult herring gulls caught at periods of no trawler activity was $13 \%$ lower than the mass of those caught at times when trawlers were active. Adult great blackbacked gulls showed a mean decline of $24 \%$. These declines exceed the range of the annual fluctuations of body mass in British herring gulls described in Coulson et al. (1983). Our findings indicate poorer body condition at times of no fishery activity.

In both species, comparisons of masses of immature guilis revealed no significant results. This might be due to the very small sample sizes (in total, 7 herring gulls and 6 great black-backed guills). 
We caught 3 adult gulls twice. To avoid replicated samples, we used only the data of the first catch in the ANCOVA. However, these few retraps consolidate our findings. They make it unlikely that only those gulls stayed on Helgoland which were already in poor condition, while gulls in better condition left the island: a great black-backed gull weighed $2375 \mathrm{~g}$ when first caught on 9 December and weighed $324 \mathrm{~g}$ less immediately after Christmas on 29 December. A herring gull first caught at Christmas weighted $1291 \mathrm{~g}$ and had increased in body mass by $290 \mathrm{~g}$ on 19 January. Another herring gull weighed $1066 \mathrm{~g}$ at Christmas and $147 \mathrm{~g}$ less when recaught on 16 February, in the middle of the trawling moratorium.
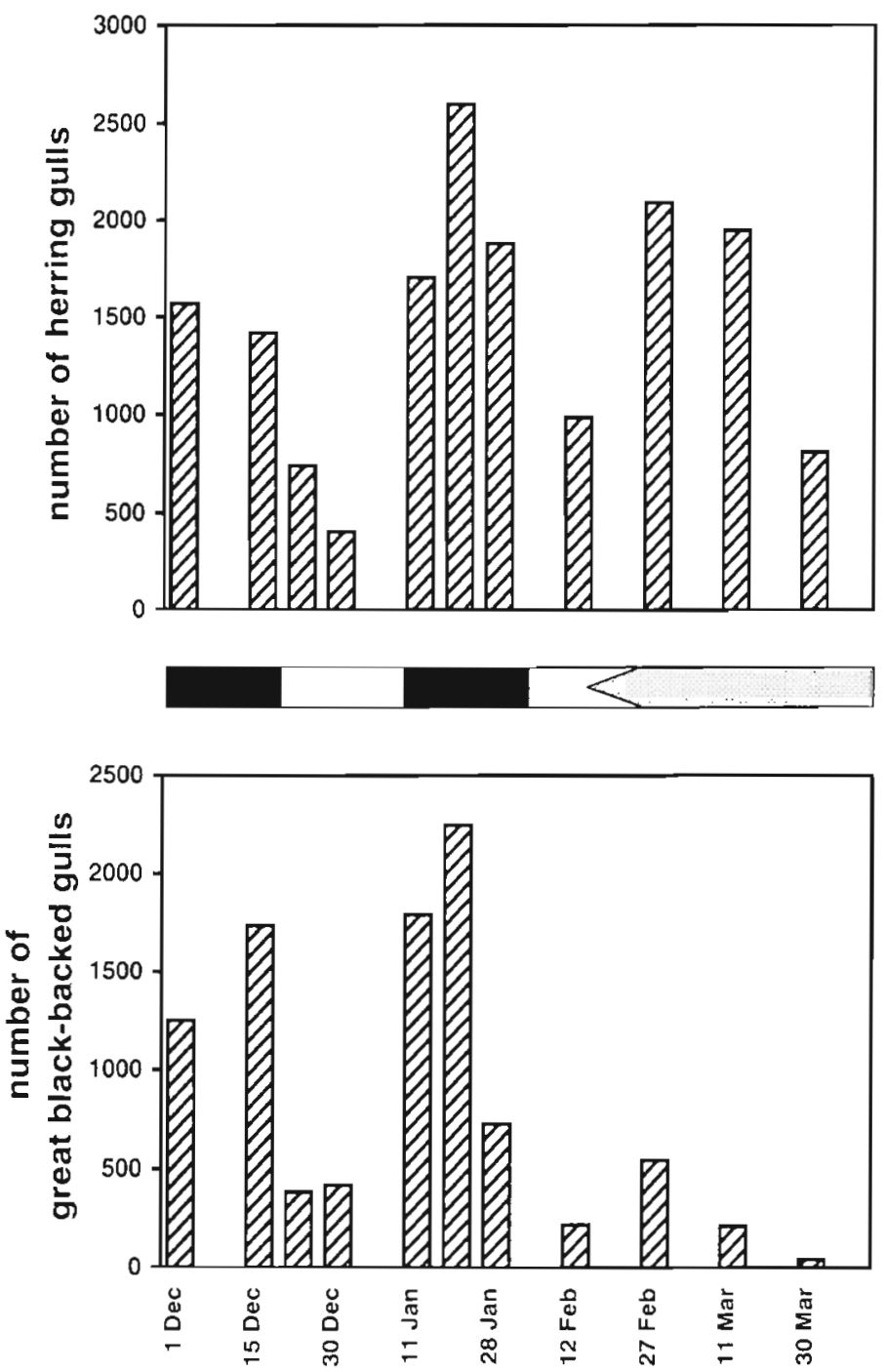

Fig. 4. Numbers of herring gulls and great black-backed gulls on Helgoland during winter 1997/98. The black parts of the horizontal bar indicate periods of fishery activities and the grey part indicates the phase with high hooknose abundance in the rocky intertidal

\section{Gull counts}

In the first half of December 1997/98, up to over 3000 herring and great black-backed gulls were resident on the island (Fig. 4). When fishery activity ceased on 16 December, gull numbers dropped dramatically to a minimum of about only 800 gulls at the end of the year. On the resumption of fishery activity in January, numbers of both herring and great black-backed gulls immediately increased to almost 5000. During the moratorium, again a large decrease in numbers was observed. The changes in gull numbers were not accompanied by any remarkable alterations of weather conditions. Despite the continuing absence of trawlers around Helgoland, herring gull numbers increased again at the end of February. This was presumably based on the appearance of a new natural food source at that time: in February and March hooknoses immigrate in large numbers to the rocky intertidal zone to spawn (A. Krüß pers. comm.). In the shallow parts of the intertidal zone these fish are readily available to the herring gulls, thereby improving the 'natural carrying capacity' of the island for this species. Hooknoses were found in $63 \%$ of the pellets collected on 25 February. A comparable increase was not observed in great black-backed gull numbers since most had already departed for their breeding areas by this time (Vauk \& Prüter 1987).

The findings for the winter $1997 / 98$ are strongly supported by counts from previous years. Despite the strong interannual variation in the numbers of resting herring gulls and great black-backed gulls, the effects of the Christmas gap are obvious since the beginning of the regular counts (Fig. 5). In the herring gull, decreases of 15 to $86 \%$ (average $55 \%$ ) were observed in all 10 winters. In the great black-backed gull, decreases in 8 winters occurred $(20$ to $80 \%$, average $60 \%$ ), whereas in 2 winters, numbers increased. In both species, all changes in numbers are highly significant ( $\chi^{2}$ goodness of fit, $\left.p<0.001\right)$.

We assume that the number of gulls present before Christmas is strongly influenced by the amount of fishery activity and thus by discard availability in these days, too (unfortunately, data on fishing activity are available only for 1997/98). In the absence of fishery activity, the island can offer only a limited amount of natural food and garbage (which should not vary much annually) for a limited number of gulls. In addition, it can be assumed that the magnitude of the proportional decrease in gull numbers during Christmas is dependent on the number of gulls present before Chritsmas; the more gulls on the island feeding on discards, then the more that must depart when this food source is exhausted. Exactly this can be observed (Fig. 6). In both herring and great black-backed gulls, the num- 

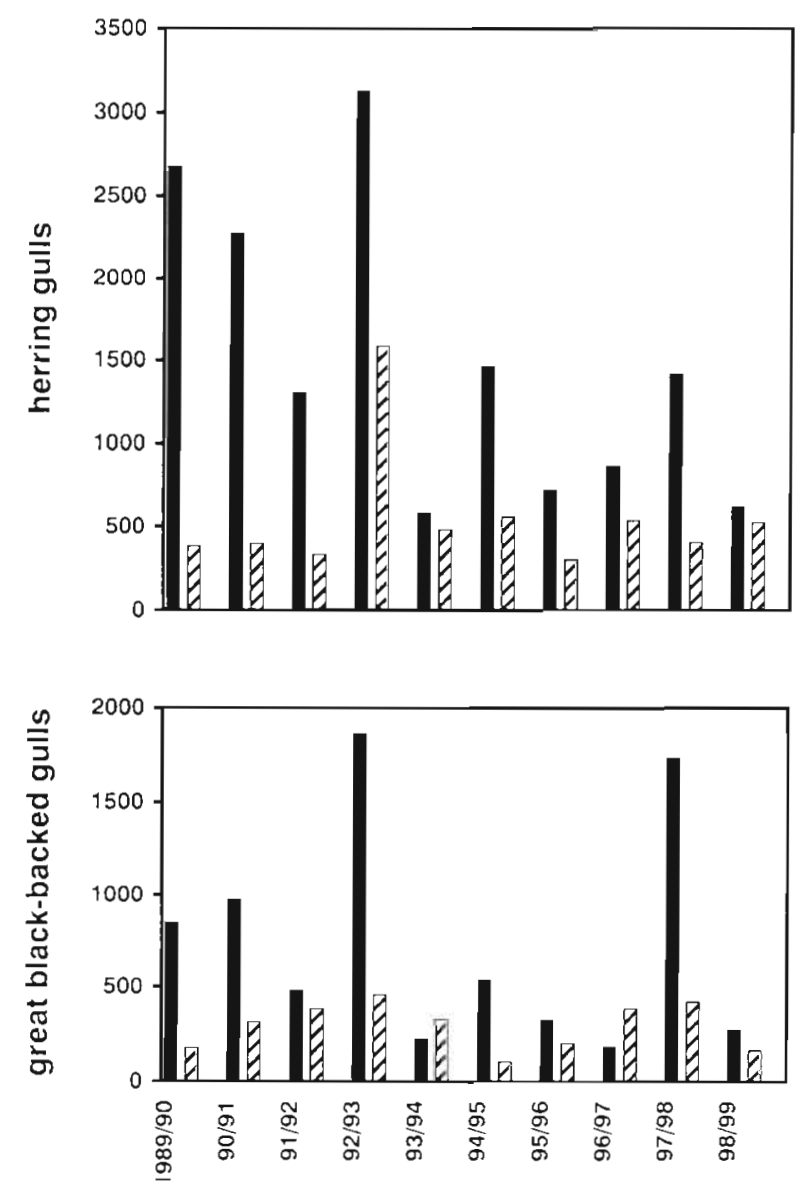

Fig. 5. Numbers of herring gulls and great black-backed gulls on Helgoland at the last count before Christmas (black bars) and the first count after Christmas (hatched bars) for the winters $1989 / 90$ to $1998 / 99$

bers present before Christmas are significantly correlated with the relative decrease from this count to the first count in the Christmas gap $\left(r_{\mathrm{s}}=0.66, p<0.05\right.$, and $r_{s}=0.75, p<0.02$, respectively, $n=10$ ).

It is not known where the gulls migrated. However, one of the great black-backed gulls ringed in December 1997 was shot on the island of Sylt (83 km NNE) 3 wk after marking, while another was observed in The Netherlands (142 km SW) 8 wk after marking

\section{CONCLUSIONS}

The herring gulls and great black-backed gulls wintering on Helgoland appear to benefit from fishery discards. Generally pronounced declines in resting numbers and a deterioration in body condition coincide with a change in food choice in non-fishing periods. For the first time, a strong influence of discard availability on numbers and body condition of large gulls in the south-eastern North Sea has been shown.
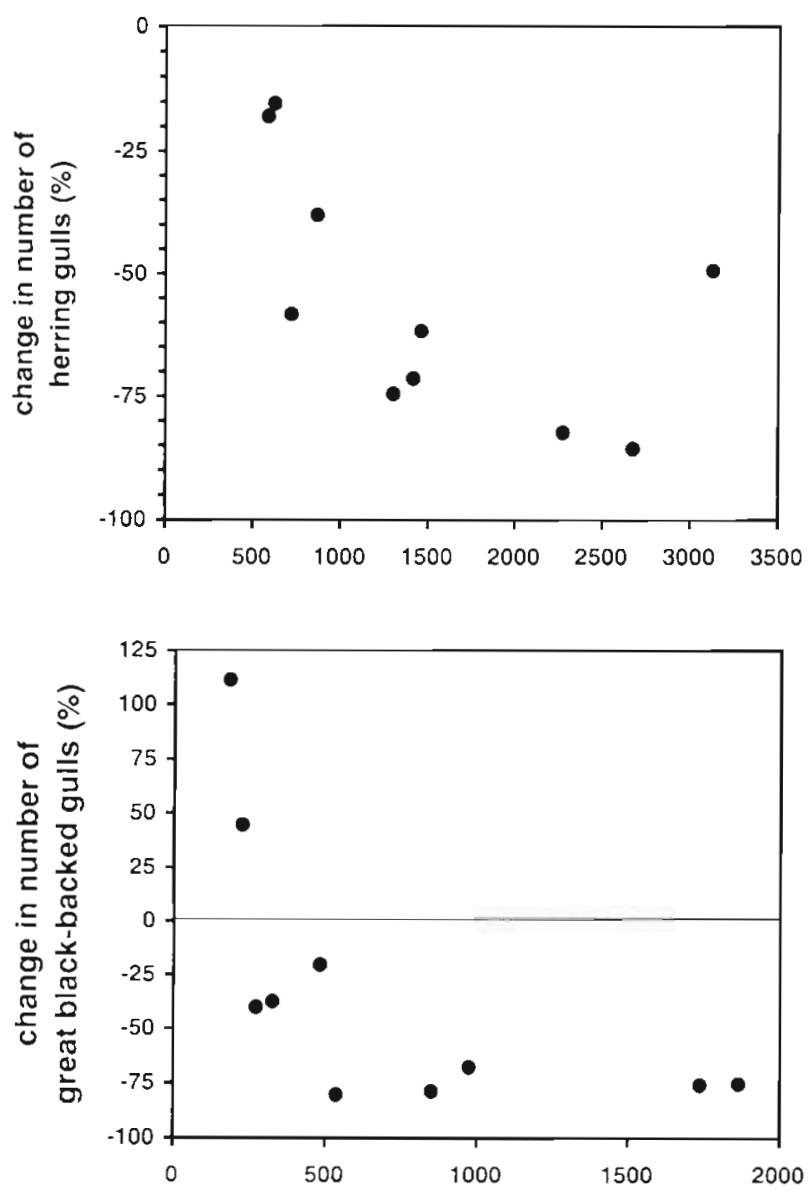

number present before Christmas

Fig. 6. Correlation of the proportional decrease of gull numbers during Christmas and the number of gulls before Christmas in herring gulls and great black-backed gulls on Helgoland in the winters $1989 / 90$ to $1998 / 99$. Note the different scales

Clearly, there is no alternative food available to support such large numbers of gulls in the Helgoland area. However, it remains unknown whether emigration to other areas could offer food sources of comparable quality and/or quantity. This seems unlikely, since resting numbers on Helgoland increase again immediately after the restart of fishing activities, thus indicating food shortage or poorer food quality in other areas too.

Our finding that fisheries influence body mass indicates that discard availability improves body condition at least in winter. As low body mass is correlated with mortality in herring gulls (Coulson et al. 1983), changes in the availability of this artificial food source most likely influence winter mortality and thus probably population dynamics of large gulls. For example, Wooller et al. (1992) and Cairns (1992) also suggested 
that food supply outside the breeding season could influence population sizes of seabirds, but our knowledge remains limited.

Acknowledgements. Carsten Keden and Jens Röw allowed us to use the Helgoland lighthouse for trawler counts and radar checks. In addition, Jens Röw showed us how to catch gulls and supported our work with various valuable hints. In addition, Jan Ole Kriegs, Sandra Knecht and many other volunteers helped catch gulls. Sven Eismann and Kathrin Hüppop counted trawlers on a couple of days. Jim B. Reid thoroughly revised our English. He, Stefan Garthe and Kathrin Hüppop usefully commented on an earlier draft of the manuscript. The 'Freunde und Förderer der Inselstation der Vogelwarte Helgoland e.V' substantially supported the project financially. We are very grateful to all of them.

\section{LITERATURE CITED}

Cairns DK (1992) Population regulation of seabird colonies. Curr Ornithol 9:37-61

Camphuysen CJ, Calvo B, Ensor K, Follestad A, Furness RW, Garthe S, Leaper G, Skov $H_{1}$ Tasker ML, Winter CJN (1995) Consumption of discards by seabirds feeding in the North Sea. NIOZ-rapport 1995-5, Netherlands Institute for Sea Research, Texel

Castilla AM, Pérez JJ (1995) Relationship between fishery activities and presence of the Audouin's gull (Larus audouinii) in the Columbretes Islands. Colon Waterbirds 18:108-112

Chapdelaine G, Rail JF (1997) Relationship between cod fishery activities and the population of herring gulls on the north shore of the Gulf of St. Lawrence, Québec, Canada. ICES J Mar Sci 54:708-713

Coulson JC, Monaghan P, Butterfield J, Duncan N, Thomas C, Shedden $C$ (1983) Seasonal changes in the herring gull in Britain: weight, moult and mortality. Ardea 71:235-244

Furness RW (1982) Competition between fisheries and seabird communities. Adv Mar Biol 20:225-307

Garthe S, Hüppop O (1994) Distribution of ship-following seabirds and their utilization of discards in the North Sea in summer. Mar Ecol Prog Ser 106:1-9

Garthe S, Camphuysen K, Furness RW (1996) Amounts of discards by commercial fisheries and their significance as food for seabirds in the North Sea. Mar Ecol Prog Ser 136:1-11

Hagemeijer EJM, Blair MJ (1997) The EBBC atlas of European breeding birds: their distribution and abundance. Poyser, London

Härkönen $T$ (1986) Otoliths of the bony fishes of the northeast Atlantic. Danbiu ApS, Hellerup

Hudson AV, Furness RW (1988) Utilization of discarded fish by scavenging seabirds behind whitefish trawlers in Shetland. J Zool Lond 215:151-166

Editorial responsibility: Otto Kinne (Editor),

Oldendorf/Luhe, Germany
Hunt GL, Furness RW (1996) Seabird/fish interactions, with particular reference to seabirds in the North Sea. ICES Coop Res Rep 216:1-87

Hüppop O, Geiß J (1995) Fischerei bestimmt Großmöwenbestände auf der Insel Helgoland. Jahresber Inst Vogelforsch $2: 21$

Klein R (1994) Silbermöwen Larus argentatus und Weißkopfmöwen Larus cachinnans auf Mülldeponien in Mecklenburg-erste Ergebnisse einer Ringfundanalyse. Vogelwelt 115:267-286

Montevecchi WA (1993) Birds as indicators of change in marine prey stocks. In: Furness RW, Greenwood JJD (eds) Birds as monitors of environmental change. Chapman and Hall, London, p 215-266

Nisbet ICT (1978) Recent changes in gull populations in the western North Atlantic. Ibis 120:129-130

Oro D (1.996) Effects of trawler discard availability on egg laying and breeding success in the lesser black-backed gull Larus fuscus in the western Mediterranean. Mar Ecol Prog Ser 132:43-46

Oro D, Bosch M, Ruiz X (1995) Effects of a trawling moratorium on the breeding success of the yellow-legged gull Larus cachinnans. Ibis 137:547-549

Paterson AM, Martínez Vilalta A, Dís JI (1992) Partial breeding failure of Audouin's gull in two Spanish colonies in 1991. Br Birds 85:97-100

Rösner HU, Prokosch P (1992) Coastal birds counted in a spring-tide rhythm - a project to determine seasonal and long-term trends of numbers in the Wadden Sea. Neth Inst Sea Res Publ Ser 20:275-279

Sachs L (1997) Angewandte Statistik. Anwendung statistischer Methoden, 8th edn. Springer, Berlin

Sell M, Vogt T (1986) Zur Winterökologie der Silbermöwe (Larus argentatus) im Binnenland: Wahl und Zuordnung der Freß- und Schlafplätze im Ruhrgebiet. Vogelwelt 107: 18-35

Spaans AL (1971) On the feeding ecology of the herring gull Larus argentatus Pont. in the northern part of the Netherlands. Ardea 59:73-188

Stühmer F, Röw J (1988) Eine Methode zum nächtlichen Fang von Möwen (Laridae) auf Helgoland. Seevögel 9 (Sonderbd): $113-114$

Vauk G, Prüter J (1987) Möwen. Arten, Bestände, Verbreitung, Probleme. Niederelbe-Verlag, Otterndorf/Niederelbe

Walter U, Becker PH (1997) Occurrence and consumption of seabirds scavenging on shrimp trawler discards in the Wadden Sea. ICES J Mar Sci 54:684-694

Watt J, Pierce GJ, Boyle PR (1997) Guide to the identification of North Sea fish using premaxillae and vertebrae. ICES Coop Res Rep 220:1-231

Weber W, Ehrich S (1998) Die Gebietsschließung in der Deutschen Bucht zum Schutz des starken 1996er Kabeljaujahrganges. Fischerblatt 46:96-101

Wooller RD, Bradley JS, Croxall JP (1992) Long-term population studies of seabirds. Trends Ecol Evol 7:111-114

Submitted: September 6, 1999; Accepted: October 21, 1999 Proofs received from author(s): February 28, 2000 